\title{
neofilolog
}

\author{
Czasopismo Polskiego Towarzystwa Neofilologicznego \\ ISSN 1429-2173, 2018, NR 51/2, 171-181 \\ http://dx.doi.org/10.14746/n.2018.51.2.4 \\ http://poltowneo.org/
}

Beata Bury

Wyższa Szkoła Filologiczna we Wrocławiu, Wydział Neofilologii https://orcid.org/0000-0002-5147-5394

beatabury86@gmail.com

\section{INVESTIGATING THE USE OF WEB 2.0 TOOLS FOR TOEFL IBT SPEAKING PRACTICE TEST}

\begin{abstract}
The use of independent and integrated speaking tasks represents a distinctive element of the TOEFL iBT speaking exam. Integrated tasks that involve synthesizing and summarizing information presented in reading and listening materials have the potential to generate new test preparation strategies. Language teachers, whether in schools or colleges, have started using Web 2.0. tools in order to prepare students for language exams. It is asserted that Web 2.0. tools support active and meaningful learning and help students to express themselves on a particular subject. This paper describes the use of Web 2.0. tools to simulate TOEFL iBT-style speaking exercises and improve the students' test taking ability in speaking during a course for kindergarten teachers in Andychów. Web-based activities were also implemented to help students overcome their fear of speaking. Also discussed are the main problems encountered, both pedagogical and technical, and what was done to solve them. Student feedback from an end-of-the-semester survey and from qualitative interviews is shared. The survey study shows that the use of Web 2.0. tools was a key feature of exam preparation on this intensive course. It is agreed that speaking skills of students can be improved through careful implementation of Web 2.0. tools.
\end{abstract}

Keywords: Web 2.0, TOEFL iBT exam, speaking practice, integrated speaking tasks

Słowa kluczowe: narzędzia Web 2.0, TOEFL iBT, zintegrowane sprawności językowe, doskonalenie mówienia 


\section{Introduction}

In the last 20 years, the world has experienced technological changes in different fields, such as business, health, economics, and education. This is due to the emergence of communication and information technologies (ICTs) (Edwards \& Bone, 2012). Kennewell et al. (2008) outlined three main purposes of ICT use:

1) ICT as an object of study;

2) ICT as a tool to obtain an answer;

3) ICT as a communication tool.

With the emergence of Web 2.0 technologies, there has been a shift from 'teachercentred' to 'student-centred' learning (Greenhow, 2011). As Selwyn (2009) stated, the focus was on students as active producers rather than passive consumers. Web 2.0 technologies help learners create, navigate, and collaborate with other users (Kuh, 2009). Song and Lee (2014) highlighted that Web 2.0 technologies provide learners with the possibility of interacting with people 'anytime' and 'anywhere.' Unlike Web 1.0, Web 2.0 allows individuals 'to contribute as much as they consume' (Anderson, 2007: 4). This interactive and social aspect can be effectively used to help language learners succeed in their learning process.

Web 2.0 tools are argued to be beneficial for students, as they make students responsible for their learning and encourage learners to start a debate or dialogue on societal, political or economic issues. McLoughlin \& Lee (2007) mention other benefits of Web 2.0 platforms, such as faster and easier access to knowledge across time and space, immediate feedback and freedom in creating content.

This article describes the use of two Web 2.0 tools, Audacity and Wiziq, to simulate TOEFL iBT-style speaking exercises and improve students' test-taking ability in speaking. This article also outlines some main problems, both pedagogical and technical, and what was done to solve them. Student feedback from an end-of-the-semester survey and qualitative interviews will be discussed.

\section{WEB 2.0 tools in education}

It cannot be denied that the Internet has been valued by educators as a powerful research and communication tool. It has simplified the way students search, manage and use information. A few years ago, finding information was a lengthy and complicated process. Today, individuals produce a large amount of information rapidly, which becomes easily accessible through a variety of devices (Wesch, 2008). The participatory nature of Web 2.0 gives netizens the possibility to collaborate with new knowledge and to create connections between individuals.

McLoughlin and Lee (2008: 665) define Web 2.0 as 'a second generation, or more personalized, communicative form of the World Wide Web that 
emphasizes active participation, connectivity, collaboration (...).' Similarly, Zhao and Kemp (2012: 232) claim that Web 2.0 technologies are 'the second generation of Web technologies which allow users to connect and interact with one another.' In order to capture the essence of Web 2.0 tools, it is necessary to refer to Merchant's (2009) four characteristic features of Web 2.0:

1) presence: Web 2.0 tools encourage individuals to actively participate in the creation of an online identity, profile or avatar. Active presence is visible by updating or interacting with other users.

2) modification: Web 2.0 tools allow users a degree of personalization through the design of the netizen's personal links or the creation of an avatar.

3) user-generated content: Web 2.0 tools provide a user-centred environment, where individuals become the content producers. For instance, YouTube provides a template for its users, but it is netizens who supply the videos, comments and other content.

4) social participation: Web 2.0 technologies invite users to participate in developing content, giving feedback, commenting and rating.

On the basis of the four characteristic features above it can be noticed that Web 2.0 tools encourage individuals to construct, develop and take part in global networks where time and place are less relevant. Web 2.0 tools give students the opportunity to become collaborators in the creation of knowledge rather than its passive recipients. By implementing Web 2.0 in English classes educators can make the learning process more enjoyable and useful.

It ought to be stressed that the use of Web 2.0 tools is significant as a way of motivating educators and learners, as an arena for developing knowledge and skills (Bryant, 2007), as well as a medium that promotes new forms of collaborative learning. Web 2.0 tools have caught the attention of universities and colleges around the world which employ them as supplements to conventional forms of the teaching and learning process.

\section{TOEFL iBT - overwiev}

The TOEFL exam has been described as a test aimed at 'measuring non-native speakers' ability to use English to communicate effectively in college and university settings' (Riley \& Wyatt, 2009). Every year people all over the world take the TOEFL exam to gain professional accreditation, apply for visas or win scholarships. The TOEFL exam is used by colleges and universities, as well as government organizations and agencies.

It has been debated whether the TOEFL is an accurate measure of a learner's true command of the English language and what influence it has on the way 
in which students are taught (Bailey, 1999). Despite this, students take the TOEFL exam in order to achieve their dream and get into university. It needs to be stressed that the types of skills required in the test, such as reformulating arguments heard in lectures in both written and spoken discourse, might prove useful in their future careers.

The TOEFL iBT appeared in 2005 as an alternative to the TOEFL paperbased and computer-based versions. The tasks in the TOEFL iBT were reformulated to match the skills required of students in an English-speaking setting, e.g. integrated speaking and writing in a task. The TOEFL iBT offers flexibility for candidates, who may take it on a regular basis and make multiple attempts over a short span of time.

\section{Statement of the problem}

According to the Ordinance issued by the Ministry of Education in Poland, nursery teachers may teach English to pre-school children. One of the requirements they need to meet is to pass an exam at B2 level. A group of 10 nursery teachers in one of the Lesser Poland's kindergartens was expected to pass an English exam in order to become qualified to teach English. Of all the exams available the TOEFL iBT exam was chosen.

The speaking section turned out to be a formidable obstacle for the participants, as it was done by computer. Nursery teachers feared that they would not be able to express their opinions clearly and smoothly in English due to the time pressure. In order to help participants overcome their fear of speaking and raise their motivation, a set of easy-to-use Web 2.0 tools was applied.

\subsection{Research questions}

The main objective of the study was to learn if Web 2.0 tools might be effectively employed to develop nursery teachers' English oral proficiency in such a way that they would be able to successfully pass the English speaking exam at B2 level. The study was guided by the following research questions:

1) Does the use of Web 2.0 tools improve participants' speaking abilites?

2) How do participants perceive the effectiveness of Web 2.0 tools in improving their English speaking skills?

3) Do participants find using selected Web 2.0 tools for speaking production useful and helpful?

It is believed that Web 2.0 tools, if properly implemented, may improve students' speaking skills. Web 2.0 encourages users to interact and collaborate with each other. The use of Web 2.0 may improve students' communication 
skills and self-expression. It is proposed that systematic and careful use of Web 2.0 tools will improve students' oral proficiency. It is claimed that students will find Web 2.0 tools useful and effective as a supplement to the English language learning.

\section{Methodology and methods}

\subsection{Participants}

As mentioned above, the participants of the study were nursery teachers who were expected to pass an English exam at B2 level in order to be qualified to teach English to kindergarten children. All of them were female teachers with differing lengths of teaching experience, ranging from 5 to 20 years. As far as age is concerned, 2 nursery teachers were below 35,3 of them below 40 , and 5 of them below 30 . Some of the nursery teachers fell under the category of digital immigrants, i.e. people born before the widespread use of technology (Prensky, 2001) and they were fearful of new technologies.

The students undertook four semesters of coursework aimed at developing the language skills needed to attain the required TOEFL iBT score to become teachers of English in the kindergarten. Participants met in class twice a week to practise speaking skills with the use of selected Web 2.0 tools. They were also assigned some homework which required the use of Audacity and Wiziq, which will be described in detail later in the article. At the end of the course, the students took the sample TOEFL iBT speaking exam.

\subsection{Methods of collecting data}

A pen and paper survey was designed to capture information relating to the way Web 2.0 technologies were perceived and used, and to analyse the effect of the interactivity of Web 2.0 tools on the student's learning. The survey contained 3 open-ended questions, which would serve as guidelines and tips for the use of Web 2.0 tools in speaking practice. The survey questions were written in English, but participants were encouraged to provide their responses in Polish in order to be able to express themselves clearly.

At the end of the course, the participants took part in a guided group interview, which was designed to ask them to reflect on their speaking performance. The interview was recorded, then transcribed, and the data were subjected to further analysis and interpretation. 


\subsection{WEB 2.0 tools used in the study}

One of the main aims of the study was to provide participants with speaking practice outside the classroom. According to Walker and White (2013: 42), 'technology provides exciting opportunities for students to interact with spoken language in ways which allow them to (...) repeat oral language in nonthreatening contexts.' Providing students with a safe environment for rehearsing and practising could gradually reduce their fear of speaking, build their confidence in speaking and improve the main skills which are required of them in English language speaking tests, namely:

1) being accurate in their use of English, which involves grammatical and lexical correctness;

2) being fluent and able to keep talk flowing smoothly without any hesitations.

It was believed that the use of Web 2.0 tools would help the participants develop their communicative competence in order to produce accurate language. Four main aspects of speaking skills were planned to be practised by means of selected Web 2.0 tools:

1) pronunciation: using different intonation patterns to communicate information;

2) performing speech acts: knowing how to express opinions;

3) managing interaction: maintaining and ending conversations, clarifying meaning;

4) organizing discourse: being able to construct discourse for different communicative purposes, e.g. giving instructions.

It cannot be denied that accuracy and fluency are difficult elements for second language learners to master. Students are often placed in a position where they are expected to produce spoken language under time pressure, which is very stressful, especially as they do not possess native-speaker compensation strategies for gaining time to think and plan, such as hesitation devices. In order to provide students with useful strategies to plan and rehearse before their final TOEFL iBT speaking exam, some user-friendly Web 2.0 tools have been implemented.

One of the Web 2.0 tools used in the study was Audacity, an audio recorder and editor which allows participants to create recordings offline. This free Web 2.0 tool gives students the opportunity to share content with other participants via e-mail or social media. Audacity proved useful in the study as students could create a dossier of their audio content which was further commented on. The participants used this Web 2.0 tool to record live audio, change the speed or pitch of the recording and create $\mathrm{mp} 3$ files for use on the platform. 
Wiziq was another Web 2.0 platform used in the study through which participants and the educator connected to share information, exchange ideas and give students immediate feedback. Wiziq provided a virtual classroom facility which allowed teachers and students to participate in real time during online delivery of classes. Students shared and embedded audio recordings into the Wiziq virtual classroom. This platform allowed participants to learn at their own pace to increase their confidence in speaking.

\subsection{Implementation of the TOEFL iBT course}

During the first day of class participants were asked to register themselves on Wiziq and familiarize themselves with the interface. Next, students received a list of what they were expected to do in the course, along with some examples of TOEFL iBT responses, audio recordings and transcripts. During the course students focused on the following iBT-type exercises:

1) Independent Speaking: students are shown a task on the screen, which is read out by a native speaker. Then, they have 15 seconds to plan their answer and 45 seconds to record their response;

2) Integrated Speaking: students are shown a short reading passage on the screen which is followed by a 1-2 minute spoken response from a native speaker. Students are allowed to take notes while listening to the passage. Then, students are given 30 seconds to plan their response and 60 seconds to deliver it into the microphone.

Students began the course with practising independent speaking tasks as this was the simplest form to assess. After explaining the task to participants and having them practise face-to-face several times, the teacher asked students to record themselves and upload the recording on Wiziq. It was noticed that simulating TOEFL iBT conditions was going to be demanding for technical reasons. The teacher consequently introduced some changes to the course.

First, time setting on the Wiziq speaking assessed tasks was abandoned as it took varying amounts of time for each student to start recording after clicking the icon. These variations in voice recorder load times meant that some participants ran out of time before they managed to complete their recordings. The time limit was abolished and the teacher manually controlled student performances. In this way, students had ample time to load the recorder and check their microphone recording levels.

Second, speaking questions were prepared in a Word document and uploaded on the Wiziq platform. It was more convenient to provide participants with the test questions in a Word document instead of asking them to start a pre-recorded question in the browser. The same quiz procedure as that 
used in Wiziq for the independent speaking test, was used for integrated speaking practice. Having read a text in a Word file, participants listened to a native speaker's opinion on a given topic. Then, after 30 seconds, students recorded their 60-second responses using Audacity.

\section{Results of the survey}

On the final day of the course, a survey was carried out in an attempt to gather feedback on the experience of the students. Participants were asked to provide answers to the following questions:

1) Do you find the selected Web 2.0 tools useful for developing speaking skills?

2) How effective were the chosen Web 2.0 tools in improving your speaking skills?

3) What problems did you face when using Web 2.0 tools?

Respondents' views and their answers to the survey questions are discussed in more detail below.

In response to the first question the majority of participants (80\%) agreed that the selected Web 2.0 tools helped them develop their speaking skills. Five participants noted that the use of Audacity and Wiziq boosted their confidence to achieve high scores in the exam. Three participants highlighted that the Web 2.0 tools helped them experience the TOEFL iBT speaking exam environment before they took the real exam. Two respondents stated that speaking in a safe asynchronous environment led to greater production and increased motivation.

The majority of participants (80\%) noted that they had no prior experience of use of Audacity or Wiziq before the course. Thanks to the course, they gained extensive knowledge and experience of these Web 2.0 tools. They learned how to distribute information, create and record their opinions and share them with other participants. Without exception, the participants agreed that the selected Web 2.0 tools provided a modern mode of communication.

When it comes to the second question, the majority of respondents (90\%) agreed that use of the Web 2.0 tools improved their speaking skills. The participants reported that their level of speaking competence rose. They increased their confidence in speaking and became aware of new ways of learning offered by Web 2.0 technologies. The respondents noted that Web 2.0 tools provided a language learning environment and experience where participants could discuss topics relevant to the TOEFL iBT format at the click of a mouse. Apart from improving their speaking skills, three respondents noticed that they became more proficient in the application of technology. One respondent stated that the selected Web 2.0 tools did not help them improve their speaking skills. This lack of enthusiasm may stem from the fact that the 
participant did not attend classes regularly and might have fallen behind with speaking assignments.

Participants faced some problems when using Web 2.0 tools during the course. $70 \%$ of the respondents agreed that at the beginning it was difficult for them to learn and manage new technologies. The participants feared they would not be able to master new technologies and complete the speaking tasks successfully. $60 \%$ of the participants faced some technical problems. They were not able to log in to Wiziq as their computer system did not work well with the course management system. Another minor disadvantage of the course was time investment. Biweekly meetings at school were not enough to improve students' speaking skills. The participants devoted their leisure time to studying the material covered in the classroom and to completing their assignments. In order to perform well in the TOEFL iBT exam, the students had to devote their free time to studying English at home.

\section{Conclusion}

The course implemented showed that Web 2.0 tools can be used effectively in speaking exam preparation. Web 2.0 tools offer an intriguing and unparalleled wealth of functionality at high level. The exploitation of this functionality offers considerable potential for the future technology-enhanced learning.

The results of the study reveal that the participants were positive towards the use of Web 2.0 tools in exam preparation. Web 2.0 tools enhanced the nursery teachers' learning experience and helped them to improve their speaking abilities. The use of Web 2.0 tools encouraged engagement and promoted active learning by helping participants work with the course material both inside and outside the classroom. The findings of the study confirmed the hypothesis that use of Web 2.0 tools improve students' communication and speaking skills as well as boost their self-confidence.

To sum up, the exploitation of Web 2.0 tools opens the classroom to the real world experiences. Voice tools, in particular, are essential prerequisites for any foreign language learning, as they allow students to enhance their speaking skills. Through voice tools students use the language communicatively and are exposed to it in diverse settings. It is believed that careful selection of voice tools and appropriately designed activities which students do outside the classroom may help them improve their speaking competence. 


\section{REFERENCES}

Anderson, P. (2007), What is Web 2.0? Ideas, technologies and implications for education. Online: http://www.ictliteracy.info/rf.pdf/Web2.0_resea rch.pdf [access date: 4.2018 ].

Bailey, K. (1999), Washback in language testing (TOEFL Monograph Series 15). Princeton, NJ: Educational Testing Service.

Bryant, T. (2007), Games as an ideal learning environment. NITLE Transformations. Online: http://www.academia.edu/164496/Games_as_an_Ideal_Learning_ Environment [access date: 4.2018].

Edwards, S., Bone J. (2012), Integrating peer assisted learning and eLearning: using innovative pedagogies to support learning and teaching in higher education settings (in) "Australian Journal of Teacher Education”, No 37. Online: DOI: 10.14221/ajte.2012v37n5.4 [access date: 4.2018].

Goswami U., Bryant P. (2007), Children's cognitive development and learning (Primary Review Research Survey 2/1a), Cambridge: University of Cambridge, Faculty of Education.

Greenhow, C., Robelia, B., Hughes, J. E. (2009), Learning, teaching, and scholarship in a digital age (in) "Educational Researcher", No 38(4), pp. 246-259. Online: http://dx.doi.org/ 10.3102/0013189X09336671 [access date: 4.2018].

Greenhow C. (2011), Youth, learning, and social media (in) "Journal of Educational Computing Research", No 45(2), pp. 139-146.

Kennewell S., Tanner H., Jones S., Beauchamp G. (2008), Analysing the use of interactive technology to implement interactive learning (in) "Journal of Computer Assisted Learning", No. 24(1), pp. 61-73.

Kuh G.D. (2009), What student affairs professionals need to know about student engagement (in) "Journal of College Student Development", No 50, pp. 683-706.

McLoughlin C., Lee M. (2008), Future learning landscapes: Transforming pedagogy through social software (in) "Innovate: Journal of Online Education", No 4(5).

McLoughlin C., Lee M. J. W. (2007), Listen and learn: A systematic review of the evidence that podcasting supports learning in higher education (in) Montgomerie C., Seale J. (eds.), Proceedings of World Conference on Educational Multimedia, Hypermedia and Telecommunications. Chesapeake, VA: AAC, pp. 1669-1677.

Merchant G. (2009), Web 2.0, new literacies, and the idea of learning through participation (in) "English Learning: Practice and Critique", No 8(3), p. 107. Prenksy M. (2001), Digital natives, digital immigrants (in) "On the Horizon", No 9(5), pp. 1-6. 
Riley R., Wyatt R. (2009), Achieve TOEFL iBT: Test-preparation. London: Marshall Cavendish Education.

Selwyn N. (2009), Faceworking: Exploring students' education-related use of "Facebook" (in) "Learning, Media and Technology", No 34 (2), pp. 157-174.

Song, L (2014), Has Web 2.0 revitalized informal learning? The relationship between Web 2.0 and informal learning (in) "Journal of Computer Assisted Learning", No 30(6), pp. 511-533. Online: doi:10.1111/jcal.12056 [access date: 4.2018 ].

Walker A., White G. (2013), Technology enhanced language learning. Connecting theory and practice. Oxford: Oxford University Press.

Wesch M. (2008), A vision of students today (and what teachers must do). Online: http://blogs.britannica.com/2008/10/a-vision-of-students-today-what-teachers-must-do [access date: 4.2018].

Zhao F., Kemp L.J. (2012), Integrating Web 2.0-based informal learning with workplace training (in) "Educational Media International", No 49 (3), pp. 231-245. 